\title{
UPAYA MENINGKATKAN PRESTASI BELAJAR SISWA DENGAN PENDEKATAN PEMBELAJARAN CONTEXTUAL TEACHING AND LEARNING (CTL) PADA SISWA SMP
}

Hifriodri Selan ${ }^{1^{*}}$, Stanislaus Amsikan ${ }^{2}$, Kondradus Yohanes Klau ${ }^{3}$

Universitas Timor

idoselan12@gmail.com

*penulis korespondensi

\section{InformasiArtikel}

\section{Kata Kunci}

Prestasi belajar

Pendekatan Pembelajaran Contextual Teaching and

Learning (CTL)

\begin{abstract}
Abstrak
Upaya Meningkatkan Prestasi Belajar Siswa Dengan Pendekatan Pembelajaran Contextual Teaching and Learning (CTL) Pada Siswa Kelas VIII SMP Negeri Fatumfaun Tahun Ajaran 2019/2020.Tujuan Penelitian ini adalah untuk meningkatkan Prestasi Belajar Siswa dengan Pendekatan pembelajaran Contextual Teahing and Learning Pada Siswa Kelas VIII SMP Negeri Fatumfaun Tahun Ajaran 2019/2020. Jenis penelitian yang digunakan dalam penelitian ini adalah Penelitian Tindakan Kelas (PTK). Subyek dalam penelitian ini adalah siswa kelas VIII SMP Negeri Fatumfaun Tahun Alajaran 2019/2020, dengan jumlah siswa sebanyak 20 orang. Penelitian ini dilaksanakan dalam dua siklus, yang masing-masing siklus terdiri atas perencanaan, tindakan, observasi dan dan refleksi. Teknik pengumpulan data yang digunakan dalam penelitian ini adalah: (1) hasil tes (2) lembar observasi.Dari hasil penelitian menunjukan pendekatan pembelajaran Contextual Teaching and Learning (CTL) dapat meningkatkan prestasi belajar siswa SMP Negeri Fatumfaun Tahun Ajaran 2019/2020. Hal ini dilihat dari presentase ketuntasan kelas yang mengalami peningkatan dari siklus I yaitu 35\% dan pada siklus II $85 \%$. Berdasarkan hasil analisis data, peneliti menyimpulkan pendekatan pembelajaran Contextual Teaching and Learning (CTL) dapat meningkatkan prestasi belajar siswa SMP Negeri Fatumfaun Tahun Ajaran 2019/2020 pada materi relasi dan fungsi.

\section{Abstract}

Efforts to Increase Student Learning Achievement with the Contextual Teaching and Learning (CTL) Learning Approach of Class VIII SMP Negeri Fatumfaun in 2019/2020 Academic Year. The purpose of this study was to improve Student Learning Achievement with the Contextual Teahing and Learning Learning Approach in of Class VIII SMP Negeri Fatumfaun in 2019/2020 Academic Year. This type of research used in this study is Classroom Action Research (CAR). The subjects in this study were eighth Class VIII SMP Negeri Fatumfaun in 2019/2020 Academic Year, with a total of 20 students. This research was conducted in two cycles, each of which consisted of planning, action, observation and reflection. Data collection techniques used in this study are: (1) test results (2) observation sheets. From the results of the study show that the Contextual Teaching and Learning (CTL) learning approach can improve the learning achievement of SMP Negeri Fatumfaun in the 2019/2020 Academic Year. This is seen from the percentage of completeness classes that have increased from the first cycle that is $35 \%$ and $85 \%$ in the second cycle. Based on the results of data analysis, the researchers concluded that the Contextual Teaching and Learning (CTL) learning approach can improve the learning achievement of SMP Negeri Fatumfaun in 2019/2020 Academic Year in relation and function material.
\end{abstract}

\section{Pendahuluan}

Matematika merupakan mata pelajaran yang mempunyai peranan penting bagi dunia pendidikan. Karena itu matematika disebut sebagai dasar untuk mengembangkan ilmu, sehingga mutlak diperlukan tenaga yang terampil dan pandai dalam matematika. Bila ilmu matematika dapat berkembang sesuai yang dibutuhkan, maka akan berguna untuk generasi yang akan datang. Reys (Runtukahu, 2014: 28) mengatakan bahwa matematika adalah studi tentang pola dan hubungan, cara berpikir dan strategi organisasi, seni, dan alat untuk memecahkan masalah-masalah abstrak dan praktis. 
Pelajaran matematika sampai saat ini masih merupakan suatu pelajaran yang kurang diminati oleh sebagian peserta didik, baik peserta didik sekolah dasar maupun peserta didik sekolah menengah. Dari sekelompok peserta didik dalam satu kelas hanya sebagian saja yang benar-benar berminat terhadap pelajaran matematika.

Salah satu permasalahan yang ditemukan peneliti adalah mengenai soal-soal matematika khususnya dalam materi relasi dan fungsi, hasil pengamatan yang dilakukan oleh peneliti selama berjalannya praktek pengalaman lapangan di SMP Negeri Fatumfaun, siswa kurang dalam menyelesaikan soal-soal relasi dan fungsi dan menyebabkan prestasi siswa kurang bagus. Berdasarkan hasil pengamatan yang dilakukan oleh peneliti selama Praktek Pengalaman Lapangan (PPL) semester genap tahun ajaran 2018/2019 di kelas VIII SMP Negeri Fatumfaun, rendahnya kemampuan siswa dalam memahami materi relasi dan fungsi ditinjau oleh proses pembelajaran, proses pembelajaran matematika dikelas belum optimal. Pendekatan pembelajaran yang digunakan dalam proses pembelajaran matematika dikelas adalah konvensional dan pembelajaran masih berpusat pada guru.

Permasalahan di atas menuntut Guru untuk menggunakan pendekatan pembelajaran yang membuat siswa aktif dalam pembelajaran sehingga siswa tidak diam, siswa aktif, rendahnya prestasi belajar siswa khususnya pada materi Relasi dan Fungsi. Hal ini berdampak pada nilai yang diperoleh. Rata-rata nilai ulangan harian materi relasi dan fungsi kebanyakan siswa hanya mencapai 60 bahkan dibawah 60, sedangkan kriteria ketuntasan minimal (KKM) yaitu 65 yang ditetapkan dari sekolah. Oleh karena itu perlu adanya pendekatan pembelajaran yang banyak melibatkan siswa aktif, siswa tidak diam, dimana siswa diberi kesempatan untuk menggali kemampuan mereka sesuai dengan apa yang mereka alami dalam kehidupan sehari-hari. Sehingga guru dalam menyampaikan materi pembelajaran perlu mengaitkan materi pembelajaran dengan apa yang dialami siswa dalam kehidupan sehari-hari.

Solusi yang tepat untuk menyelesaikan masalah di atas adalah pembelajaran Contextual teaching and learning (CTL). pembelajaran kontekstual atau Contextual teaching and learning (CTL) merupakan suatu konsepsi yang membuat guru mengaitkan konteks mata pelajaran dengan situasi dunia nyata dan memotivasi siswa membuat hubungan antara pengetahuan dan penerapannya dalam kehidupan sehari-hari.

\section{Sub Judul}

\section{Belajar}

Belajar merupakan suatu proses usaha yang dilakukan seseorang untuk memperoleh suatu perubahan tingkah laku yang baru secara keseluruhan sebagai hasil pengalannya sendiri dalam interaksi dengan lingkungannya.

Prinsip belajar ialah petunjuk atau cara yang perlu diikuti untuk melakukan kegiatan belajar. Siswa akan berhasil dalam belajarnya jika memperhatikan prinsip-prinsip belajar. Prinsip belajar akan menjadi pedoman bagi siswa dalam belajar.

Menurut Dimyati (2009: 42) prinsip-prinsip belajar itu adalah sebagai berikut:

\section{Perhatian dan motivasi}

Perhatian mempunyai peranan yang penting dalam kegiatan belajar. Tanpa adanya perhatian tidak mungkin akan terjadi sebuah proses belajar. Perhatian terhadap pelajaran akan timbul pada siswa apabila bahan pelajaran sesuai dengan kebutuhannya. Apabila bahan pelajaran itu dirasakan sebagai sesuatu yang dibutuhkan, diperlukan untuk belajar lebih lanjut atau diperlukan dalam kehidupan sehari-hari, maka akan membangkitkan motivasi untuk mempelajarinya. Di samping perhatian, motivasi juga mempunyai peranan penting dalam kegiatan belajar. Motivasi adalah tenaga yang menggerakkan dan mengarahkan aktivitas seseorang, tanpa adanya motivasi seseorang tidak dapat melakukan kegiatan dengan sebaik-baiknya. Oleh karena itu, dengan perhatian dan motivasi maka siswa akan melakukan proses belajar atau membiasakan diri dengan belajar dengan baik, sehingga ia dapat memperoleh hasil yang ia inginkan.

\section{Keaktifan}


Dalam setiap proses belajar, siswa selalu menampakkan keaktifan. Keaktifan itu beraneka ragam bentuknya. Mulai dari kegiatan fisik yang mudah kita amati sampai kegiatan psikis yang susah diamati. Kegiatan fisik bisa berupa membaca, mendengar, menulis, berlatih keterampilanketerampilan, dan sebagainya. Contoh kegiatan psikis misalnya menggunakan khasanah pengetahuan yang dimiliki dalam memecahkan masalah yang dihadapi, membandingkan satu konsep dengan yang lain, menyimpulkan hasil percobaan, dan kegiatan psikis yang lain.

3. Keterlibatan langsung/berpengalaman

Belajar haruslah dilakukan sendiri oleh siswa, belajar merupakan proses mengamali, dan belajar tiak bisa dilimpahkan kepada orang lain. Menurut Edgar Dale dalam Dimyati (2009: 45), "belajar yang baik adalah belajar melalui pengalaman langsung". Dalam belajar melalui pengalaman langsung siswa tidak sekedar mengamati secara langsung tetapi ia harus menghayati, terlibat langsung dalam perbuatan, dan bertanggung jawab terhadap hasilnya. Namundemikian, perilaku keterlibatan siswa secara langsung dalam kegiatan belajar pembelajaran dapat diharapkan mewujudkan keaktifan siswa.

4. Pengulangan

Prinsip belajar yang menekankan perlunya pengulangan barangkali yang paling tua adalah yang dikemukakan oleh teori Psikologi Daya. Menurut teori ini belajar adalah melatih daya-daya yang ada pada manusia yang terdiri atas daya mengamat, menanggap, mengingat, mengkhayal, merasakan, berpikir, dan sebagainya. Dengan mengadakan pengulangan maka daya-daya tersebut akan berkembang, dan juga apabila daya-daya tersebut dilatih dengan pengadaan pengulanganpengulangan maka akan menjadi sempurna. Selain itu dengan adanya pengulangan maka akan membentuk respons yang benar dan akan dapat membentuk kebiasaan-kebiasaan. Contohnya pada saat belajar tidak hanya membaca akan tetapi mengerjakan soal-soal latihan, mengulang materi yang belum dipahami, dan lain-lain

5. Tantangan

Tantangan yang dihadapi alam bahan belajar membuat siswa bergairah untuk mengatasinya. Bahan belajar yang baru, yang banyak mengandung masalah yang perlu dipecahkan membuat siswa tertantang untuk mempelajarinya. Pelajaran yang memberi kesempatan pada siswa untuk menemukan konsep-konsep, prinsip-prinsip, dan generalisasi akan menyebabkan siswa berusaha mencari dan menemukan konsep-konsep, prinsip-prinsip, dan generalisasi tersebut. Contoh dari prinsip tantanganini yaitu, melakukan eksperimen, melaksanakan tugas terbimbing maupun mandiri, atau mencari tahu pemecahan suatu masalah.

6. Balikan dan penguatan

Siswa selalu membutuhkan suatu kepastian dari kegiatan yang akan dilakukan, dengan demikian siswa akan selalu memiliki pengetahuan tentang hasil, yang sekaligus merupakan penguatan bagi dirinya sendiri. Seorang siswa belajar lebih banyak bilamana setiap langkah segera diberikan penguatan. Hal ini timbul karena kesadaran adanya kebutuhan untuk memperoleh balikan dan sekaligus penguatan bagi setiap kegiatan yang dilakukan. Untuk memperoleh balikan penguatan bentuk-bentuk perilaku siswa yang memungkinkan di antaranya adalah dengan segera mencocokkan jawaban dengan kunci jawaban, menerima kenyataan terhadap skor/nilai yang dicapai, atau menerima teguran dari guru/orang tua karena hasil belajar yang jelek.

7. Perbedaan individual

Setiap siswa memiliki karakteristik sendiri-sendiri yang berbeda satu dengan yang lain. Kesadaran bahwa dirinya berbeda dengan siswa lain, akan membantu siswa menentukan cara belajar dan sarana belajar bagi dirinya sendiri. Contohnya pada saat siswa menentukan tempat duduk dikelas, menyusun jadwal belajar, dan lain-lain.

Berdasarkan pendapat ahli, dapat disimpulkan bahwa prinsip belajar meliputi perhatian dan motivasi, keaktifan, keterlibatan langsung/berpengalaman, pengulangan, tantangan, balikan dan penguatan, serta perbedaan individual.

Proses pembelajaran tidak terlepas dari ciri-ciri tertentu, salah satunya, Menurut Rusman (2015: 13-16) menyampaikan ada delapan ciri-ciri belajar, berikut diantaranya : 1). Perubahan yang disengaja (intensional) dan didasari 2). Perubahan yang berkesinambungan (kontinu) 3). 
Perubahan yang fungsional 4). Perubahan yang bersifat positif 5). Perubahan bersifat aktif 6). Perubahan yang bersifat permanen 7). Perubahan yang terjadi bertujuan dan terarah 8). Perubahan perilaku secara menyeluruh.

Berdasarkan pendapat di atas dapat disimpulkan bahwa ciri-ciri belajar adalah siswa yang dapat bertindak untuk belajar atau pembelajar yang dapat berlanggsung di mana saja dan sepanjang hayat pembelajar. Pembelajar akan memperoleh hasi belajar dan pengalaman hidup untuk dapat memecahkan masalah belajar juga dapat menjadikan perubahan secara sadar yang bersifat fungsional, positif, sementara, bertujuan, dan mencakup seluruh aspek.

\section{Pembelajaran Contextual Teaching And Learning}

Pembelajaran (Contextual Teaching and Learning) melibatkan tujuh komponen utama pembelajaran efektif, yaitu konstruktivisme, bertanya, menemukan, masyarakat belajar, pemodelan, refleksi dan penilaian sebenarnya. Sebuah kelas dapat dikatakan menggunakan pendekatan CTL jika menerapkan ketujuh komponen tersebut dalam pembelajarannya.

Penerapan Contextual Teaching \& Learning yang terjadi di dalam kelas secara garis besar langkahnya sebagai berikut, Riyanto (2009: 168-169): 1) Kembangkan pikiran bahwa anak akan belajar lebih bermakna dengan cara bekerja sendiri, dan mengkonstruksikan sendiri pengetahuan keterampilan barunya 2) Laksanakanlah sejauh mungkin kegiatan inquiri semua topic 3) Kembangkan sifat ingin tahu siswa dengan bertanya 4) Ciptakan masyarakat belajar (belajar dalam kelompok-kelompok) 5) Hadirkan model sebagai contoh pembelajaran 6) Lakukan refleksi diakhir pertemuan 7) Lakukan penilaian sebenarnya dengan berbagai cara

Sedangkan menurut Yamin (2013: 50-51), secara sederhana proses pembelajaran dengan pembelajaran Contextual Teaching \& Learning sebagai berikut:

1. Pembukaan/persiapan

a. Guru mengingatkan kepada siswa tentang materi pelajaran yang lalu dan mengaitkan dengan materi pelajaran yang akan dipelajari terutama tentang tata cara pemecahan masalah.

b. Guru menyampaikan tujuan pembelajaran.

c. Siswa memperhatikan tujuan belajar, tidak hanya untuk menguasai materi pelajaran tetapi juga untuk mempelajari strategi memahami masalah.

2. Penyajian

a. Guru mengemukakan masalah, memberi contoh bagaimana cara memecahkan masalah, merumuskan masalah, menyelesaikan masalah, menjawab masalah dan mengaitkan dengan kehidupan dunia nyata.

b. Siswa dan guru membuat generalisasi dan menggunakan alat-alat pemecahan masalah.

c. Siswa mengerjakan tugas.

d. Siswa melakukan penguatan internal terhadap materi.

e. Guru mendorong siswa untuk menghasilkan jawaban kritis dan kreatif.

f. Siswa membuatkan kesimpulan terhadap materi yang dipelajarinya.

3. Penutup

a. Guru memberikan penguatan terhadap kesimpulan yang diberikan siswa.

b. Siswa meneguhkan kesimpulan sesuai penguatan yang diberikan guru.

c. Siswa mengerjakan tes atau tugas yang diberikan guru.

d. Guru membuat kesimpulan hasil proses pembelajaran.

\section{Prestasi Belajar}

Prestasi belajar adalah sebuah kalimat yang terdiri dari dua kata, yakni prestasi dan belajar. Prestasi belajar di bidang pendidikan adalah hasil dari pengukuran terhadap peserta didik yang meliputi faktor kognitif, afektif dan psikomotor.Setelah mengikuti proses pembelajaran yang diukur dengan menggunakan instrumen tes atau instrumen yang relevan. Prestasi belajar dapat diukur melalui tes yang sering dikenal dengan tes prestasi belajar. 
Menurut Hetika (2008: 23), prestasi belajar adalah pencapaian atau kecakapan yang dinampakkan dalam keahlian atau kumpulan pengetahuan. Sedangkan Menurut Harjati (2008: 43), prestasi merupakan hasil usaha yang dilakukan dan menghasilkan perubahan yang dinyatakan dalam bentuk simbol untuk menunjukkan kemampuan pencapaian dalam hasil kerja dalam waktu tertentu.

Hipotesis dalam penelitian ini adalah Melalui Pembelajaran Contextual Teaching \& Learning (CTL) dapat meningkatkan Prestasi Belajar Matematika.

\section{Metode}

Penelitian ini merupakan penelitian tindakan kelas (PTK) yang dilakukan dalam dua siklus. Masing - masing siklus melalui tahap perencanaan, pelaksanaan, observasi dan refleksi.

Subyek dalam penelitian ini adalah siswa kelas VIII SMP Negeri Fatumfaun Tahun pelajaran 2019/2020. yang berjumlah 19 orang yang terdiri dari 10 orang siswa laki-laki dan 9 orang siswa perempuan, teknik pengumpulan data pada penelitian ini, meliputi lembar observasi dan tes hasil belajar. Cara pengumpulan data dalam penelitian ini adalah dengan cara pengamatan dan data tes hasil belajar.

Prosedur dalam penelitian ini dilaksanankan dalam beberapa siklus dan setiap siklus meliputi kegiatan perencanaan(planning), tindakan (action), observasi (observation), dan refleksi (reflection).

Teknik analisis data dalam penelitian tindakan kelas ini adalah analisis data hasil observasi terhadap aktivitas siswa dan guru dan analisis data hasil tes. Analisis data hasil tes meliputi ketuntasan perorangan dan ketuntasan kelas.

Indikator keberhasilan dalam penelitian ini adalah jika dalam suatu kelas, ketuntasan semua siswa lebih atau sama dengan $65 \%$ maka proses pembelajaran dengan menggunakan pendekatan pembelajaran Contextual Teaching \& Learning dikatakan berhasil. Tetapi jika ketuntasan siswa kurang dari $65 \%$ maka proses pembelajaran dengan menggunakan pendekatan pembelajaran Contextual Teaching \& Learning belum berhasil dan perlu diperhatikan mengenai metode dalam pembelajarannya.

\section{Hasil dan Pembahasan}

a. Siklus I

Kegiatan pembelajaran siklus I berlangsung selama 2 kali pertemuan, dengan pertemuan kedua digunakan untuk tes siklus I. Pertemuan pertama untuk proses pembelajaran dilaksanakan pada hari Senin, 4 November 2019 selama 2 jam pembelajaran dimulai tepat pukul 09:25-10:45 WITA dengan jumlah siswa yang hadir 19 orang. Dengan Indikator : 1. Menyebutkan masalah sehari-hari yang berkaitan dengan relasi dan fungsi 2. Menyatakan fungsi dengan diagram panah, koordinat cartesius dan himpunan pasangan berurutan. Pertemuan kedua dilaksanakan pada hari Rabu, 6 November 2019 yang berlangsung dari pukul 07:30-09:30 WITA, dengan jumlah siswa 19 orang. Untuk mengetahui kemampuan siswa maka peneliti menggunakan waktu pertemuan kedua ini untuk melakukan tes siklus I yang dikerjakan secara individu. Selama pelaksanaan tes, masing-masing siswa mengerjakan soal-soal tes tersebut secara individu sesuai waktu yang telah ditetapkan. Setelah selesai tes, pekerjaan dikumpulkan dan untuk membantu siswa agar pelajaran tetap diingat maka siswa diberikan pekerjaan rumah (PR).

Langkah- langkah dalam siklus I diantaranya:

a). Perencanaan

Setelah ditetapkan untuk menerapkan pendekatan pembelajaran CTL maka peneliti melakukan halhal sebagai berikut: mempersiapkan perangkat pembelajaran berupa silabus, RPP, dan bahan ajar, membuat pedoman pengamatan, menyusun soal tes setiap siklus dengan menggunakan pendekatan CTL.

b). Pelaksanaan Tindakan 
Tindakan yang dilakukan peneliti pada pertemuan pertama adalah menerapkan pendekatan pembelajaran contextual teaching and learningsesuai dengan RPP. Peneliti melakukan proses pembelajaran dengan mengikuti langkah - langkah.

c). Observasi

1. Pengamatan proses pembelajaran

Proses kegiatan pembelajaran siklus I belum berjalan dengan lancar dan belum sesuai dengan apa yang diharapkan. Siswa nampak kurang aktif dan kurang bersemangat. Siswa juga kurang berani untuk mengemukakan pendapat atau bertanya, siswa masih kurang dalam memberi pemahaman kepada teman kelompok dan ada beberapa siswa yang kurang memahami materi yang dipelajari, yang menyebabkan prestasi siswa menurun. Hal ini dapat dilihat pada hasil tes siklus I dengan persentase ketuntasan kelas $37 \%$.

2. Hasil Tes

Setelah mengikuti proses pembelajaran pada pertemuan pertama dengan menggunakan pendekatan pembelajaran CTL siswa diberi tes dan diperoleh hasil tes siklus I pada pertemuan kedua, terlihat pada tabel dibawah ini:

\begin{tabular}{|c|c|c|c|}
\hline NO & NAMA & NILAI & KET \\
\hline 1. & LB & 90 & T \\
\hline 2. & GK & 100 & T \\
\hline 3. & EPK & 100 & T \\
\hline 4. & VGE & 90 & T \\
\hline 5. & MJB & 100 & T \\
\hline 6. & AT & 90 & T \\
\hline 7. & AI & 100 & T \\
\hline 8. & EJT & 20 & TT \\
\hline 9. & AST & 60 & TT \\
\hline 10. & EEM & 60 & TT \\
\hline 11. & MB & 60 & TT \\
\hline 12. & MA & 60 & TT \\
\hline 13. & JB & 60 & TT \\
\hline 14. & MAA & 60 & TT \\
\hline 15. & DS & 60 & TT \\
\hline 16. & VK & 50 & TT \\
\hline 17. & DB & 60 & TT \\
\hline 18. & JDBA & 60 & TT \\
\hline 19. & EEM & 20 & TT \\
\hline
\end{tabular}

\section{Tabel. 1Data hasil tes siklus I}

Keterangan: siswa yang lulus adalah siswa yang mencapai nilai 65

Berdasarkan tabel I di atas diperoleh:

a. Ketuntasan Perorang

Terdapat 7 orang siswa yang mencapai KKM yaitu 65 dan 12 orang siswa belum mencapai KKM yang ditentukan oleh sekolah

b. Ketuntasan kelas

Dari data nilai tes siklus I yang terlihat pada Tabel 1 siswa-siswi yang berjumlah 19 orang telah mengikuti tes, dengan jumlah siswa yang tuntas sebanyak 7 orang dengan ketuntasan kelas sebesar $37 \%$. dan jumlah siswa yang belum tuntas sebanyak 12 orang atau persentasinya $63 \%$

d). Refleksi

Berdasarkan analisis di atas prestasi belajar belum mencapai indikator keberhasilan yang ditetapkan oleh sekolah. peneliti harus melakukan perbaikan sebagai berikut:

a. Siswa belum memiliki kemampuan untuk merespon pembelajaran dengan menggunakan pendekatan pembelajaran CTL karena siswa merasa model pembelajaran yang digunakan baru 
maka sebelum melalui pembelajaran peneliti harus menjelaskan secara singkat tentang pendekatan pembelajaran CTL.

b. Keaktifan siswa secara pribadi maupun kelompok dalam diskusi kelompok yang interaktif belum muncul, siswa masih ragu dalam mempresentasikan hasil kerja kelompok dan juga siswa masih kurang dalam menjawab pertanyaan yang diberikan oleh kelompok lain disebabkan karena kemampuan siswa beragam sehingga menuntut perhatian guru secara khusus.

c. Melalui hasil penelitian ini menunjukan bahwa pembelajaran dengan menggunakan pendekatan pembelajaran CTL belum mencapai indikator keberhasilan yang ditentukan $65 \%$. Hal ini dapat dilihat dari hasil tes tes siklus I 37\% maka perlu di perbaiki pada siklus berikutnya.

\section{b. Siklus II}

Kegiatan pembelajaran siklus II sama dengan siklus I, dimana siklus II berlangsung selama dua kali pertemuan, dengan pertemuan terakhir digunakan untuk tes siklus II. Pertemuan pertama untuk pembelajaran dilaksanakan pada hari Rabu, 13 November 2019 selama 2 jam pelajaran, yang dimulai tepat pukul 07:30-09:30 WITA, dengan jumlah siswa yang hadir 19 orang. Peneliti menyampaikan materi dengan Indikator : 1. Menyatakan suatu fungsi atau pemetaan 2. Menyatakan soal yang berkaitan dengan soal korespondensi 3. Menyelesaikan soal tentang penerapan relasi dan fungsi. Pertemuan yang kedua dilaksanakan pada hari Jumat, 15 November 2019 yang berlangsung dari 10:25-11:45 WITA, dengan jumlah siswa yang hadir 19 orang. Dan selanjutnya peneliti memberikan tes untuk siklus II, untuk mengetahui kemampuan siswa setelah dilakukan proses pembelajaran maka peneliti melakukan tes siklus II diakhir pertemuan. Selama pelaksanaan tes masing-masing siswa mengerjakan soal yang diberikan secara individu, sesuai waktu yang telah ditetapkan. Setelah selesai tes siklus II, hasil pekerjaan siswa dikumpulkan.

Langkah- langkah penelitian siklus II adalah sebagai berikut:

\section{a). Perencanaan}

Berdasarkan hasil refleksi siklus I, peneliti merencanakan perbaikan lagi bagi siklus II karena pelaksanaan yang dilakukan peneliti terhadap siswa masih ada kekurangan-kekurangan seperti presentasi ketuntasan kelas yang diperoleh melalui hasil tes pada siklus I adalah $37 \%$ ini belum mencapai indikator ketuntasan atau keberhasilan ditetapkan yaitu: 63\%, sehingga peneliti merencanakan tindakan siklus II. Dengan berpedoman pada siklus I, peneliti melakukan penelitian tindakan siklus II. Dalam siklus II yang harus di perbaiki adalah kesalahan dan kekurangan yang dilakukan pada siklus I.

b). Pelaksanaan Tindakan

Tindakan yang dilakukan peneliti pada pertemuan pertama adalah menerapkan pendekatan pembelajaran contextual teaching and learningsesuai dengan RPP.

c) Observasi

1. Pengamatan Proses Pembelajran

Proses pembelajaran pada siklus II sudah berjalan dengan lancar. Siswa tampak bersemangat yang tercermin dari ekspresi wajah siswa. Hal ini di sebabkan karena ada beberapa faktor diantarannya adalah siswa mulai aktif saat proses pembelajaran, siswa mengikuti pelajaran dengan baik, siswa mulai terbiasa dengan pendekatan pembelajran CTL, siswa menyampaikan soal atau masalah yang berkaitan dengan kehidupan sehari-harinya.

2. Hasil Tes

Setelah mengikuti proses pembelajaran pada pertemuan pertama dengan mengunakan pendekatan pembelajran CTL dieroleh hasil tes siklus II pada pertemuan kedua, terlihat pada tabel dibawah ini:

\begin{tabular}{|c|c|c|c|}
\hline No & $\begin{array}{c}\text { Nama } \\
\text { Siswa }\end{array}$ & Nilai & Keterangan \\
\hline
\end{tabular}




\begin{tabular}{|c|c|c|c|}
\hline 1. & LB & 100 & $\mathrm{~T}$ \\
\hline 2. & GK & 100 & $\mathrm{~T}$ \\
\hline 3. & EPK & 100 & $\mathrm{~T}$ \\
\hline 4. & VE & 100 & $\mathrm{~T}$ \\
\hline 5. & AT & 100 & $\mathrm{~T}$ \\
\hline 6. & AI & 100 & $\mathrm{~T}$ \\
\hline 7. & EJT & 100 & $\mathrm{~T}$ \\
\hline 8. & EEM & 90 & $\mathrm{~T}$ \\
\hline 9. & MB & 56,6 & $\mathrm{TT}$ \\
\hline 10. & MA & 100 & $\mathrm{~T}$ \\
\hline 11. & JB & 100 & $\mathrm{~T}$ \\
\hline 12. & MAA & 100 & $\mathrm{~T}$ \\
\hline 13. & DS & 90 & $\mathrm{~T}$ \\
\hline 14. & VK & 90 & $\mathrm{~T}$ \\
\hline 15. & DB & 90 & $\mathrm{~T}$ \\
\hline 16. & JDP & 100 & $\mathrm{~T}$ \\
\hline 17. & EEM & 100 & $\mathrm{~T}$ \\
\hline 18. & SAS & 90 & $\mathrm{~T}$ \\
\hline 19. & AST & 56,6 & $\mathrm{TT}$ \\
\hline
\end{tabular}

\section{Tabel. 2Data hasil tes siklus II}

Keterangan siswa yang lulus adalah siswa yang mencapai nilai minimal 65 Berdasarkan tabel 2 di atas, diperoleh:
a. Ketuntasan Perorangan
Terdapat 17 orang siswa yang mencapai KKM dan 2 yang tidak tuntas

b. Ketuntasan Kelas

Dari data nilai tes pada siklus II yang terdapat pada tabel di atas, siswa-siswi yang berjumlah 19 orang telah mengikuti tes, dengan jumlah ketuntasan 17 orang siswa atau presentase ketuntasannya $89 \%$, ini berarti data nilai tes pada siklus II dari siswa yang berjumlah 19 orang telah mencapai ketuntasan klasikal atau kelas, walaupun masih ada 2 orang yang masih memperoleh nilai di bawah standar ketetapan sekolah yaitu 65\% namun sesuai pengamatan peneliti adalah siswa yang belum tuntas tapi nilainya hampir mendekati ketuntasan. Ketuntasan individunya yakni 65 atau presentasenya $65 \%$. Dengan demikian, hasil tes siklus II peneliti tuntas melaksanakannya. Karena dari 19 orang siswa yang tuntas 17 orang siswa dikatakan tuntas melebihi standar yang ditetapkan oleh sekolah, maka peneliti berhasil menerapkan pembelajaran dengan menggunakan pendekatan pembelajran CTL.

\section{d). Refleksi}

Setelah melaksanakan kegiatan pada siklus II peneliti mengambil kesimpulannya adalah sebagai berikut :

1. Siswa sudah memiliki kemampuan untuk merespon pembelajaran dengan menggunakan pendekatan pembelajaran CTL, karena siswa merasa model pembelajaran yang digunakan baru maka sebelum memulai pembelajaran peneliti harus menjelaskan secara singkat tentang pendekatan pembelajaran CTL.

2. Keaktifan siswa secara pribadi maupun kelompok dalam diskusi kelompok yang interaktif sudah bagus disebabkan karena siswa sudah berani untuk bertanya atau mengemukakan pendapat atau idenya.

3. Hasil belajar siswa pada siklus II ini telah mencapai ketuntasan. Hal ini dapat dilihat berdasarkan hasi tes siklus I 37\% dan meningkat pada siklus II menjadi 89\%.

Hasil pengamatan terhadap aktivitas siswa selama tindakan siklus I menunjukan bahwa aktivitas siswa pada siklus I termasuk kategori rendah, karena ada beberapa aspek yang diamati seperti (kurang tertip dalam kelompok, masih kurang dalam memberi pemahaman kepada temannya, dan masih banyak yang belum aktif dalam kelompok, siswa masih ragu dalam mempresentasikan hasil 
kerja kelompok, dan masih kurang dalam menjawab pertanyaan yang di berikan oleh kelompok lain). Hal ini disebabkan karena pendekatan pembelajaran Contextual Teaching and Learning merupakan pendekatan pembelajaran yang baru diterapkan dalam proses belajar mengajar di lokasi penelitian. Walaupun hasil observasi terhadap peneliti menggambarkan bahwa peneliti melakukan kegiatan pembelajaran sesuai dengan pendekatan pembelajaran Contextual Teaching and Learning namun masih ada kekurangan-kekurangan yang ditemukan dalam proses belajar mengajar.Dari 19 orang siswa peserta tes, yang telah mencapai standar ketuntasan sebanyak 7 orang sehingga persentase ketuntasan kelas yang dicapai pada siklus I sebesar 37\%, sedangkan 12 orang lainnya belum dinyatakan tuntas. Pencapaian ketuntasan kelas pada siklus I belum memenuhi standar ketuntasan sehingga dilanjutkan penelitian pada siklus II dengan bahan refleksinya adalah memberi motivasi dan apersepsi kepada siswa sebelum memulai proses pembelajran, memberi bimbingan kepada setiap kelompok atau siswa yang mengalami kesulitan dalam berdiskusi.Merujuk pada refleksi siklus I sehingga pelaksanaan penelitian pada siklus II menggambarkan perubahan peningkatan aktivitas siswa selama pelaksanaan pembelajaran berlangsung. Aktivitas siswa pada siklus II sudah termasuk kategori tinggi, karena semua aspek yang diamati tidak ada masalah yang ditemukan. Hal inipun berakibat pada prestasi belajar siswa dimana hasil tes siklus II menunjukan bahwa dari 19 siswa peserta tes, 17 siswa dinyatakan tuntas dengan persentase ketuntasan kelas yang dicapai sebesar 89\%.Perkembangan interaksi antara siswa dengan siswa serta siswa dengan guru dari siklus ke siklus mengalami perubahan dalam proses belajar mengajar. Dalam proses belajar siswa terlihat aktif berpikir tentang permasalahan yang disampaikan oleh guru dapat berdiskusi dengan baik serta dapat mengutarakan pendapat. Ini menggambarkan peningkatan prestasi belajar seperti yang dinyatakan oleh Nurhadi dkk dalam muslich (2008: 41) yang mengemukakan bahwa pendekatan pembelajaran CTL adalah suatu pendekatan pembelajaran yang dapat menumbuhkan minat dan hasil belajar siswa terhadap pembelajaran matematika karena karena lewat pendekatan ini siswa lebih aktif menemukan sendiri, dapat berpikir kritis, dapat saling tukar pikiran dengan teman untuk menemukan masalah. Berdasarkan uraian pada pembahasan di atas disimpulkan bahwa dengan pendekatan pembelajaran Contextual Teaching and Learning dapat meningkatkan prestasi belajar siswa, sesuai dengan hasil yang telah diperoleh pada hasil tes setiap siklus.

\section{Simpulan}

Berdasarkan hasil penelitian dan pembahasan, maka peneliti menyimpulkan bahwa dengan menggunakan pendekatan pembelajaran Contextual Teaching And Learning dapat menigkatkan prestasi belajar siswa SMP Negeri Fatumfaun Tahun Ajaran 2019/2020. Hal ini dilihat dengan berdasarkan tes siklus I sebesar $37 \%$ dan pada siklus II $89 \%$.

\section{Referensi}

Dimyati, Mujiyono 2009. Belajar dan pembelajaran. Jakarta: Rineka Cipta

Rusman. 2015. Pembelajaran Tematik Terpadu, Teori Praktik dan Penilaian

Runtukahu, J Tombokan dan Kandou, Selpius. 2014. Pembelajaran Matematika Dasar Bagi Anak Berkesulitan Belajar. Yogyakarta: Ar-ruzz Media.

Riyanto, Y. 2009. Paradigma baru pembelajaran: sebagai referensi bagi guru, pendidik dalam implementasi pembelajaran yang efektif dan berkualitas. Penerbit kencana Prenada Media Group. Jakarta. $288 \mathrm{hlm}$.

Harjati. 2008. Psikologi Belajar. Jakarta: PT. Rineka Cipta.

Hetika 2008. http:// PRESTASI BELAJAR >> Pengertian Prestasi Belajar|belajarpsikologi.com. di akses 4 januari 2012.

Muslich, 2008. Pembelajaran Berbasis Kompotensi dan Kontekstual. Jakarta: Bumi Aksara

Yamin, M. 2013. Strategi dan metode dalam model pembelajaran. Jakarta: referensi (GP Press Group). 